\title{
Production and characterisation of a marine Halomonas surface-active exopolymer
}

\author{
Tony Gutierrez ${ }^{1,2}$ (D) $\cdot$ Gordon Morris ${ }^{3} \cdot$ Dave Ellis $^{4} \cdot$ Barbara Mulloy $^{5} \cdot$ Michael D. Aitken $^{2}$
}

Received: 27 August 2019 / Revised: 13 November 2019 / Accepted: 22 November 2019 / Published online: 7 December 2019

(C) The Author(s) 2019

\begin{abstract}
During screening for novel emulsifiers and surfactants, a marine gammaproteobacterium, Halomonas sp. MCTG39a, was isolated and selected for its production of an extracellular emulsifying agent, P39a. This polymer was produced by the new isolate during growth in a modified Zobell's 2216 medium amended with $1 \%$ glucose, and was extractable by cold ethanol precipitation. Chemical, chromatographic and nuclear magnetic resonance spectroscopic analysis confirmed P39a to be a high-molecularweight $(\sim 261,000 \mathrm{~g} / \mathrm{mol})$ glycoprotein composed of carbohydrate $(17.2 \%)$ and protein $(36.4 \%)$. The polymer exhibited high emulsifying activities against a range of oil substrates that included straight-chain aliphatics, mono- and alkyl- aromatics and cycloparaffins. In general, higher emulsification values were measured under low (0.1 M PBS) compared to high (synthetic seawater) ionic strength conditions, indicating that low ionic strength is more favourable for emulsification by the P39a polymer. However, as observed with other bacterial emulsifying agents, the polymer emulsified some aromatic hydrocarbon species, as well as refined and crude oils, more effectively under high ionic strength conditions, which we posit could be due to steric adsorption to these substrates as may be conferred by the protein fraction of the polymer. Furthermore, the polymer effected a positive influence on the degradation of phenanthrene by other marine bacteria, such as the specialist PAH-degrader Polycyclovorans algicola. Collectively, based on the ability of this Halomonas high-molecular-weight glycoprotein to emulsify a range of pure hydrocarbon species, as well as refined and crude oils, it shows promise for the bioremediation of contaminated sites.
\end{abstract}

Keywords Exopolymers $\cdot$ Halomonas $\cdot$ Hydrocarbons $\cdot$ Biodegradation $\cdot$ Marine environment

\section{Introduction}

Surface-active agents are a group of chemicals that play an important role in various industrial processes and products due to

Tony Gutierrez

tony.gutierrez@hw.ac.uk

1 Institute of Mechanical, Process and Energy Engineering (IMPEE), School of Engineering and Physical Sciences, Heriot-Watt University, Edinburgh, UK

2 Department of Environmental Sciences and Engineering, Gillings School of Global Public Health,, University of North Carolina, Chapel Hill, NC, USA

3 Department of Chemical Sciences, School of Applied Sciences, University of Huddersfield, Huddersfield, UK

4 Institute of Chemical Sciences (ICS), School of Engineering and Physical Sciences, Heriot-Watt University, Edinburgh, UK

5 Institute of Pharmaceutical Science, King's College London, London, UK their ability to interface between hydrophobic (non-aqueous) and hydrophilic (aqueous) phases. These chemicals can be divided into two major types: (1) Surfactants, which are generally of low-molecular-weight and denoted by their ability to reduce surface and/or interfacial tension between two-phase media, and (2) emulsifiers, which are biopolymers of high-molecularweight and are characterised by their ability to form oil-in-water or water-in-oil emulsions and/or in stabilizing the emulsion droplets. Surfactants and emulsifiers are used in almost every sector of modern industry, particularly in personal care products and household cleaners. To fulfill their demand, the majority of these chemicals are produced from non-renewable sources, such as petrochemicals. In recent years, however, efforts to discover new types of these chemicals from natural sources - denoted as biosurfactants and bioemulsifiers-have gained pace. Surface-active agents produced from natural sources are environmentally friendlier compared to their synthetic counterparts, as their biosynthesis can be performed using renewable feedstocks (e.g. agricultural waste) and importantly they are biodegradable (Panilaitis et al. 2006). 
The marine environment is considered a largely untapped source for the discovery of new types of surface-active agents. This is highlighted in the enormous diversity of bacteria that exists in the world's seas and oceans that could yield novel types of these biomolecules (Kalogerakis et al. 2015). Marine bacteria can secrete exopolymeric substances (EPS) that can consist of any combination of proteins and/or lipids within a major polysaccharide backbone. These macromolecules serve important functions to the producing microorganism(s) and its neighbours, as well as to animals and plants, and also have wider implications to the marine environment, including to global biogeochemical cycles and climate change (Decho and Gutierrez 2017). For example, EPS produced by marine bacteria have been shown involved in sequestering dissolved cationic species (Loaec et al. 1997, 1998; Steiner et al. 1976) and, more broadly, in biogeochemical processes (see Decho and Gutierrez 2017). These macromolecules have also been shown to mediate the initial attachment of bacteria to surfaces in biofilm formation (Decho 2000a, b; Thavasi and Banat 2014), in interacting with dissolved and/or particulate organic matter (Decho and Gutierrez 2017 and references therein), including in the formation of marine oil snow (Gutierrez et al. 2013b) and aggregates with micro- and nano-plastic particles in seawater (Summers et al. 2018).

Halomonads are slight to moderately halophilic and oligotrophic organisms that are ubiquitous to marine and hypersaline environments (Arahal and Ventosa 2006) and recognised for producing large quantities of EPS. EPS from various Halomonas species have been reported to confer excellent rheological properties (Arias et al. 2003; Bèjar et al. 1996; Bouchotroch et al. 2000; Calvo et al. 1998; Martinez-Checa et al. 2002; Mata et al. 2006) and to bind transition metals and dyes (Arias et al. 2003; Gutierrez et al. 2009; Mata et al. 2006). Some species have been reported to produce EPS with surface-active properties, which may provide a mechanism to scavenge poorly soluble, hydrophobic substrates (e.g. lipids, hydrocarbons) that the cells can then utilise for growth in the marine environment. For example, the EPS of some Halomonas spp. has been shown to increase the bioavailability of aliphatic (Pepi et al. 2005) and aromatic (Alva and Peyton 2003; Garcia et al. 2004, 2005; Gutierrez et al. 2013b) compounds. In this study, we characterise the EPS produced by a Halomonas species that was isolated from a coastal surface seawater environment. We investigate its production during growth of the organism in a batch fermenter, and analyse the chemico-physiological properties of the extracted EPS, including its potential to emulsify a range of crude and refined petrochemical and hydrocarbon substrates. Based on our findings, we offer potential avenues to develop the biopolymer for biotechnological application, including as a promising candidate for the bioremediation of sites contaminated with petrochemical pollutants.

\section{Materials and methods}

\section{Strain isolation, growth and identification}

Surface water samples were collected in July of 2009 off Long Beach, California. To isolate hydrocarbon-degrading bacteria, a synthetic seawater medium, ONR7a (Dyksterhouse et al. 1995), was supplemented with $n$-hexadecane (Hex) to $1 \%$ (v/v) final concentration. Isolation was performed by streaking $5 \mu \mathrm{l}$ samples of the seawater onto the ONR7a+Hex agar plates. The plates were stored in closed plastic bags in the dark at $21{ }^{\circ} \mathrm{C}$ for 2 to 3 weeks. Isolates displaying distinct colonial morphologies were picked, purified and examined for growth on $n$-hexadecane as the sole carbon and energy source. Purified isolates were stored frozen at $-80{ }^{\circ} \mathrm{C}$ in $20 \%(\mathrm{v} / \mathrm{v})$ glycerol for subsequent sequencing and further work.

One isolate, strain MCTG39a, was selected for its ability to produce high emulsifying activity during growth in $\mathrm{ZM} / 1$ broth (Blackburn et al. 1989) amended with glucose at $1 \%$ $(w / v)$ concentration. During growth, samples were taken periodically for emulsification assays - washed cell pellets and cell-free supernatants (centrifuged at $13,000 \times g$ for $10 \mathrm{~min}$ ) were assayed. Growth was monitored by spectrophotometric measurement at $600 \mathrm{~nm}$ of whole culture broth. Growth experiments were repeated at least three times, and all analyses were performed in triplicate.

Total genomic DNA from MCTG39a was recovered using a Wizard genomic DNA purification kit (Promega, Madison, WI), according to the manufacturer's instructions. The $16 \mathrm{~S}$ rRNA gene of the strain was amplified by PCR with primers 27f (Wilmotte et al. 1993) and 1492r (Lane 1991), and then sequenced at the University of North Carolina Genome Analysis Facility. Sequences were analysed using the program Sequencher 4.8 (Gene Codes Corp., Ann Arbor, MI) and submitted to GenBank. The BLAST search program and RDP-II (Maidak et al. 1999) were used to check for close relatives and phylogenetic affiliation. The search results were used as a guide for tree construction. Clustal_X (Thompson et al. 1994) was used to align the 16S rRNA gene sequence of strain MCTG39a with close relatives and to construct a neighbourjoining tree with Treeview (WIN32) version 1.5.2 (Page 1996). The trees were bootstrapped 1000 times, and gaps in the alignment were ignored.

\section{Production and extraction of emulsifying exopolymer}

Strain MCTG39a was grown in a 14-L bench-top FerMac 320 (Electrolab, UK) fermenter containing 41 of $\mathrm{ZM} / 1$ medium amended with glucose $(1 \% \mathrm{w} / \mathrm{v})$ and incubated at $28^{\circ} \mathrm{C}$ with mixing at $150 \mathrm{rev} \mathrm{min}^{-1}$. The fermenter was fitted with temperature, $\mathrm{pH}$ and dissolved oxygen probes (Broadley James, USA), and data was captured with FermaTec software (Electrolab, UK). To monitor production of the emulsifying 
exopolymer, samples $(2 \mathrm{~mL})$ from the fermenter were taken daily and the emulsifying activity of the cell-free spent medium assayed.

The fermenter was terminated when maximal emulsifying activities were reached $\left(\mathrm{EI}_{24}>100 \%\right)$. The emulsifying exopolymer was then extracted from the biomass by centrifugation $(10,000 \times g ; 20 \mathrm{~min})$ of the spent medium followed by filtration through $0.2 \mu \mathrm{m}$ filters. To isolate the emulsifying exopolymer, the cell-free permeate was treated with $\mathrm{KCl}$ $(7.5 \% \mathrm{w} / \mathrm{v})$ and two volumes of cold $99 \%$ ethanol. The precipitate was allowed to settle overnight at $4{ }^{\circ} \mathrm{C}$, recovered by centrifugation, and subsequently dialysed against distilled water and freeze-dried. The resultant dried material, labeled P39a, was used in all subsequent characterization experiments.

\section{Emulsification assays and tensiometry}

To assay for emulsifying activity during growth of strain MCTG39a, a modified version of the method described by Cooper and Goldenberg (1987) was used. For this, samples of culture broth were centrifuged $(13,000 \times \mathrm{g} ; 10 \mathrm{~min})$ and then filtered $(0.2 \mu \mathrm{m})$ to completely remove cells. For the emulsification assay, $2 \mathrm{ml}$ of cell-free fraction was mixed with an equal volume of $n$-hexadecane in acid-washed $(0.1 \mathrm{~N} \mathrm{HCl})$ screw-cap glass tubes $(100 \times 13 \mathrm{~mm})$. The tubes were then manually shaken (15 s), vigorously vortexed (15 s) to homogeneity, left to stand for $10 \mathrm{~min}$ and then shaken as before. After allowing the mixture to stand for $24 \mathrm{~h}$ at $21^{\circ} \mathrm{C}$, the height of the emulsion layer was measured and expressed as a percentage $\left(\mathrm{EI}_{24}\right)$ of the total original height of the oil in the tube.

To determine the specificity of the P39a exopolymer to emulsify various hydrocarbon substrates, including some crude oils and their refined petro-derivatives, we employed a modified emulsification assay based on that described by Cirigliano and Carman (1984). For this, 2.5-ml solutions of the extracted polymer $(0.02 \% \mathrm{w} / \mathrm{v})$ dissolved in $0.1 \mathrm{M}$ phosphate-buffered saline (PBS; $\mathrm{pH} 7.0$ ) or filtered $(0.2 \mu \mathrm{m})$ synthetic filtered seawater (FSW; $\mathrm{pH}$ 8.0) were emulsified against $0.4 \mathrm{ml}$ of the test oil, as described previously (Gutierrez et al. 2007). After mixing, the solutions were allowed to stand for $60 \mathrm{~min}$ prior to measuring the absorbance of the lower aqueous phase by spectrophotometry at $540 \mathrm{~nm}$. Emulsification activities are expressed as the average absorbance at $540 \mathrm{~nm}$ values derived from triplicate experiments when testing each of the oils in PBS or FSW.

Surface tension measurements were performed using a Kibron EZ-Pi Plus surface tensiometer equipped with a Dyne probe for static du Noüy ring measurements. Samples of strain MCTG39a growing in ONR 7a or ZM/1 broth, and of cell-free fractions, were measured for surfactancy. The isolated P39a exopolymer at various concentrations dissolved in water were also measured to evaluate its potential to reduce the surface tension of water.

\section{Chemical analysis of the exopolymer}

To determine the monosaccharide composition, triplicate samples $(10 \mu \mathrm{l}$ at $1 \%$ [wt/vol]) of the P39a polymer were dissolved in $500 \mu \mathrm{l}$ of $2 \mathrm{M}$ trifluroacetic acid and hydrolysed at $100^{\circ} \mathrm{C}$ for $4 \mathrm{~h}$, as previously described (Gutierrez et al. 2008). The samples were then prepared for analysis by high-performance anion exchange chromatography using a Dionex Carbopac PA-20 column on a Dionex ICS-3000 Ion Chromatography System (Dionex Corp. Sunnyvale, USA) and eluted with $0.01 \mathrm{M} \mathrm{NaOH}$ at a flow rate of $0.3 \mathrm{ml} / \mathrm{min}$ for $20 \mathrm{~min}$ to elute neutral sugars and then for a further 20 min with $1 \mathrm{M} \mathrm{NaOAc}$ in $0.15 \mathrm{M} \mathrm{NaOH}$ to elute uronic acid residues. The monosaccharide composition was then quantified using external standards. The total carbohydrate content was calculated from the individual amounts of monosaccharides.

For determination of amino acid composition, acid hydrolysis was performed on $3 \mathrm{mg}$ of the P39a polymer. Samples were hydrolyzed at $110^{\circ} \mathrm{C}$ in $2 \mathrm{ml}$ of $6 \mathrm{M} \mathrm{HCl}$ for $24 \mathrm{~h}$ under vacuum and then dehydrated and diluted in $0.1 \mathrm{M} \mathrm{HCl}$. Analysis was performed using a Waters 2695 Separations Module, a 2487 Dual Absorbance Detector and a 1515 Isocratic high-performance liquid chromatography (HPLC) Pump equipped with a $300 \times 3.5 \mathrm{~mm}$ Laborsevice $7-\mu \mathrm{m}$ resin cation exchange column. Quantification was performed using a Sigma Amino Acid Standard (AAS18) external calibrant. The total protein content was calculated from the individual amounts of amino acids.

For molecular weight and polydispersity determination of polymer P39a, size-exclusion chromatography coupled to multi-angle laser light scattering (SEC-MALLS) was used. For this, the polymer was dissolved in distilled water at $\sim 0.3 \%$ (wt/vol) and then analysed by size-exclusion chromatography at ambient temperature on a PL Aquagel guard column (Polymer Labs, Amherst, USA) which was linked in series with PL Aquagel-OH 60, PL Aquagel-OH 50 and PL Aquagel-OH 40, and was eluted with $0.1 \mathrm{M}$ $\mathrm{NaNO}_{3}$ at a flow rate of $0.7 \mathrm{ml} / \mathrm{min}$. The eluent was then detected online firstly by a DAWN EOS light scattering detector (Wyatt Technology, Santa Barbara, USA) and by a rEX differential refractometer (Wyatt Technology, Santa Barbara, USA). The refractive index increment, $d n / d c$ was taken to be that of a typical polysaccharide $(0.150 \mathrm{ml} / \mathrm{g})$ (Harding et al. 1991; Theisen et al. 2000). Samples were run in triplicate.

For ${ }^{1} \mathrm{H}$ nuclear magnetic resonance (NMR) analysis, the P39a polymer was dissolved in $\mathrm{D}_{2} \mathrm{O}$ (to $\sim 0.7 \mathrm{ml}$ ) containing 
$1 \mu \mathrm{l}$ of $2 \%$ acetone in $\mathrm{D}_{2} \mathrm{O}$ as an internal reference. Proton NMR spectra were acquired at $60{ }^{\circ} \mathrm{C}$ using a Bruker AVIII $400 \mathrm{MHz}$ spectrometer. Temperature regulation utilized a BVT3200 temperature control unit. One-dimensional spectra were acquired using the Bruker pulse program 'zgesp' featuring a water-suppression sequence. The number of scans was set at 256, the acquisition time was ca. $1 \mathrm{~s}$ and a linebroadening factor of $1 \mathrm{~Hz}$ was imposed on the data prior to processing. TOCSY spectra were acquired using the Bruker pulse program 'dipsi2esgpph' featuring a water-suppression sequence. $\mathrm{TD}(1)$ was set at $256 \mathrm{~W}$ and the data was truncated in $\mathrm{f}_{2}$ with $\mathrm{TD}_{\text {eff }}$ set to $800 \mathrm{~W}, \mathrm{TD}(2)$ being set to $2048 \mathrm{~W}$. The mixing time was set to $120 \mathrm{~ms}$.

\section{Effect of the exopolymer on the biodegradation of hydrocarbons}

Phenanthrene was selected as a model PAH to investigate the influence of the P39a exopolymer produced by Halomonas strain MCTG39a on the bioavailability and biodegradation of this compound by the marine PAH-degrading 'specialist' Polycyclovorans algicola TG408 (Gutierrez et al. 2013a). For these experiments, sterile 40-ml screw-cap EPA glass vials were prepared, each containing increasing concentrations of P39a from strain MCTG39a-0.0, 0.1, 0.2 and $0.4 \mathrm{mg} / \mathrm{ml}$ - in $5 \mathrm{ml}$ of ONR7a medium. Each vial was inoculated with $200 \mu \mathrm{l}$ of cell suspension. In order to maintain a consistent mass transfer of phenanthrene in each vial, a twophase system employing heptamethylnonane (HMN), as previously described (Gutierrez et al. 2013b), was used within which phenanthrene (PHE) was dissolved. HMN is generally considered recalcitrant to biodegradation (Wodzinski and Larocca 1977), although some studies have reported its partial breakdown by microorganisms (Katsivela et al. 2003; Rontani and Giusti 1986). Preliminary experiments in our laboratory with $P$. algicola TG408 yielded no growth on HMN as a sole carbon and energy source. Hence, it was applied in this study as a delivery system for transferring phenanthrene into the aqueous phase. For this, $2 \mathrm{ml}$ of the HMN-PHE solution was carefully dispensed above the aqueous phase in each vial in order to maintain the surface area of the oil-water interface constant and standardized between treatments. All the vials were incubated with gentle rotary shaking $(100 \mathrm{rpm})$ at $21{ }^{\circ} \mathrm{C}$ for a period of 12 days. Each treatment was performed in triplicate. Sampling was performed by taking $2.5-\mu \mathrm{l}$ volumes from the HMN-PHE phase in each vial at the time of inoculation and thereafter as indicated. The samples were immediately dissolved in an appropriate volume of ethyl acetate and their absorbance measured spectrophotometrically at $251 \mathrm{~nm}$. The $A_{251}$ values were converted to concentrations of phenanthrene using $63,0001 \mathrm{~mol}^{-1} \mathrm{~cm}^{-1}$ as the extinction coefficient (Thomas and Burgess 2007). A decrease in the concentration of phenanthrene was attributed to its degradation in the aqueous phase. Incubations prepared as above, but uninoculated, were also run in order to test the potential of the P39a polymer to transfer the phenanthrene from the HMN layer into the lower aqueous phase. The purified P39a exopolymer did not serve as a source of carbon and energy since control experiments inoculated with only P. algicola TG408 and the P39a exopolymer did not yield any significant growth (results not shown).

Following from these experiments with a pure hydrocarbon substrate, we subsequently evaluated the P39a exopolymer for its potential to increase the bioavailability and biodegradation of a common petrochemical fuel, in this case diesel. For this, we selected a marine bacterial strain, Halomonas sp. strain TGOS-10, as this organism has been shown to positively respond to petrochemical contamination in the marine environment - this strain was isolated from an oil-slick seawater sample collected during the active phase of the Deepwater Horizon oil spill in the Gulf of Mexico and, based on a community sequencing survey of the impacted site, the strain had become enriched during the spill (Gutierrez et al. 2013b). For these experiments, sterile 250-ml screw-cap Erlenmeyer flasks were prepared, each containing $125 \mathrm{ml}$ of ONR7 a medium, $1 \mathrm{ml}$ of diesel, and either $1 \mathrm{mg}$ or $4 \mathrm{mg}$ of the P39a exopolymer - respectively $8 \mathrm{mg} / \mathrm{L}$ and $32 \mathrm{mg} / \mathrm{L}$ final concentrations. Each flask was inoculated with $200 \mu \mathrm{l}$ of pre-washed cells of strain MCTG39a. All the flasks were incubated with gentle rotary shaking $(100 \mathrm{rpm})$ at $21^{\circ} \mathrm{C}$ for a period of 7 days. Controls included flasks that were inoculated and amended with diesel in the same way but without any added exopolymer, and flasks inoculated and treated with $2 \mathrm{ml}$ of $10 \mathrm{M} \mathrm{HCl}$ to act as acid-killed controls. Each treatment was performed in triplicate. To analyse for the biodegradation of the diesel, at day 7, each flask was extracted several times with 30-ml aliquots of ethyl acetate. The ethyl acetate fractions from each flask were pooled, dehydrated with anhydrous $\mathrm{MgSO}_{4}$, filtered and then vacuum evaporated to remove the ethyl acetate. The resultant diesel residue from each flask was then weighed. Biodegradation of the diesel by strain TGOS10 was determined by comparing the residual weight of the diesel from incubations containing live cells of this organism to incubations with acid-killed cells.

\section{Statistical analysis}

A Student's $t$ test was performed to test for significant differences $(P<0.05)$ in the biodegradation tests and emulsification of the different hydrocarbon substrates tested.

\section{Nucleotide sequence accession number}

The 16S rRNA gene sequence of strain MCTG39a was deposited with GenBank under accession number MH463546. 


\section{Results}

\section{Isolation and identification of strain MCTG39a}

Screening of a number of isolates for production of surfaceactive agents identified one isolate, strain MCTG39a, which was found to produce an extracellular emulsifying agent (designated P39a) with the ability to produce stable oil-in-water and water-in-oil emulsions with $n$-hexadecane and various other oil substrates. Strain MCTG39a grew well in ZM/1 medium and cell-free extracts produced high emulsification activities $\left(\mathrm{EI}_{24}\right.$ of $\left.100-120 \%\right)$ when $\mathrm{ZM} / 1$ was supplemented with $1 \%(\mathrm{w} / \mathrm{v})$ glucose. The same cell extract only partially reduced the surface tension of the culture medium to values of between 55.0 and $60.0 \mathrm{mN} / \mathrm{m}$ during growth.

An almost complete sequence of the 16S rRNA gene (1439 bp) was obtained for strain MCTG39a, which was identified to be a member of the genus Halomonas. From a BLASTN analysis, strain MCTG39a shared 100\% 16S rRNA sequence identity with Halomonas sp. strain TG39 (Gutierrez et al. 2007) and Halomonas sp. strain TGOS-10 (Gutierrez et al. 2013b) — both of which are also producers of surface-active exopolymers (Gutierrez et al. 2007, 2013b). The closest match to a type strain was with Halomonas titanicae $\mathrm{BH}^{\mathrm{T}}$ (99\% sequence identity) isolated from the RMS Titanic (Sanchez-Porro et al. 2010). These and other related sequences were used to construct a neighbourjoining tree (Fig. 1). The new isolate, identified as Halomonas sp. strain MCTG39a, was deposited in the Deutsche Sammlung von Mikroorganismen und Zellkulturen (DSMZ) culture collection (DSM 7827).

\section{Cell growth and P39a production dynamics}

Figure 2 shows the average dissolved oxygen, $\mathrm{pH}$, turbidity (at $540 \mathrm{~nm}$ ), glucose concentrations and emulsification index (after $24 \mathrm{~h}$ ) over the course of batch fermentation for $142 \mathrm{~h}$ at a constant temperature of $28^{\circ} \mathrm{C}$. After an initial lag of $\sim 21 \mathrm{~h}$, glucose concentrations decreased at a steady rate of $4.1 \mu \mathrm{moles} / \mathrm{ml} /$ day, and reaching lowest values by the termination of the fermentation ( $35 \mu \mathrm{moles} / \mathrm{ml})$. This coincided with an increase in cell turbidity (a proxy for cell growth) that reached stationary phase after around $80 \mathrm{~h}$. Glucose consumption was indicated by a concomitant decrease in oxygen concentrations that stabilized by $\sim 50 \mathrm{~h}$ to $\sim 29 \%$ of oxygen saturation in the medium. This also coincided with stabilization of the $\mathrm{pH}$, which increased from an initial value of $\sim 7.2$ to $\sim 7.6$ after $\sim 50 \mathrm{~h}$. Monitoring $\mathrm{EI}_{24}$ values indicated that the emulsifying exopolymer (P39a) was produced by the cells within $12 \mathrm{~h}$ and reached maximal levels by $120 \mathrm{~h}$, although $>80 \%$ of emulsifier production was reached by $60 \mathrm{~h}$. Thus, the emulsifying activity was found tightly coupled to the exponential growth of the cells.

\section{Chemical composition and molecular mass of the P39a exopolymer}

A monosaccharide analysis of the P39a exopolymer produced by Halomonas sp. strain MCTG39a showed that it contained a carbohydrate content of $17.2 \pm 1.9 \%$ of the total weight of

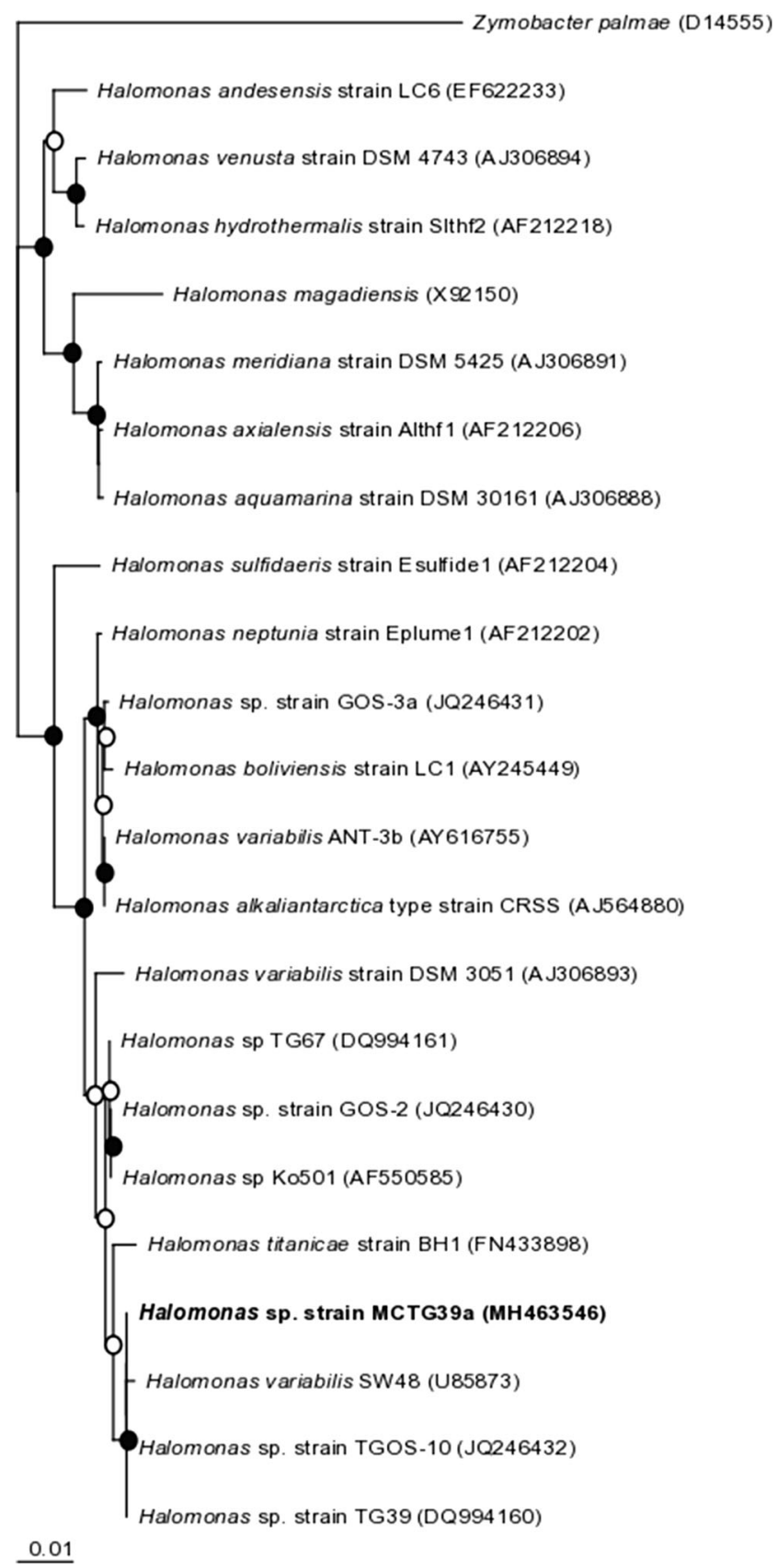

Fig. 1 Phylogenetic tree of Halomonas sp. strain MCTG39a (bold) shown alongside closely related sequences and type strains from GenBank. The tree was constructed using the neighbour-joining algorithm. Filled circles indicate nodes with bootstrap values (1000 bootstrap replications) greater than $90 \%$; open circles indicate bootstrap values greater than $60 \%$. Accession numbers of all sequences are given in parentheses. Zymobacter palmae (D14555) was used as outgroup. The scale bar indicates the difference of number of substitutions per site 
Fig. 2 Emulsifier production during fermentation with Halomonas sp. strain MCTG39a in $\mathrm{ZM} / 1$ liquid medium amended with $1 \%(\mathrm{w} / \mathrm{v})$ glucose.

Emulsifying activities were derived from cell-free culture broth after the removal of cells by centrifugation. Each data point is the mean of results from triplicate samples. Solid circles, optical density at $540 \mathrm{~nm} ; \mathrm{X}, \mathrm{pH}$; empty circles, dissolved oxygen; closed squares, emulsification index after $24 \mathrm{~h}\left(\mathrm{EI}_{24}\right)$; empty squares, glucose concentration in $\mu$ moles $\mathrm{mL}^{-1}$. Some error bars are smaller than the symbols

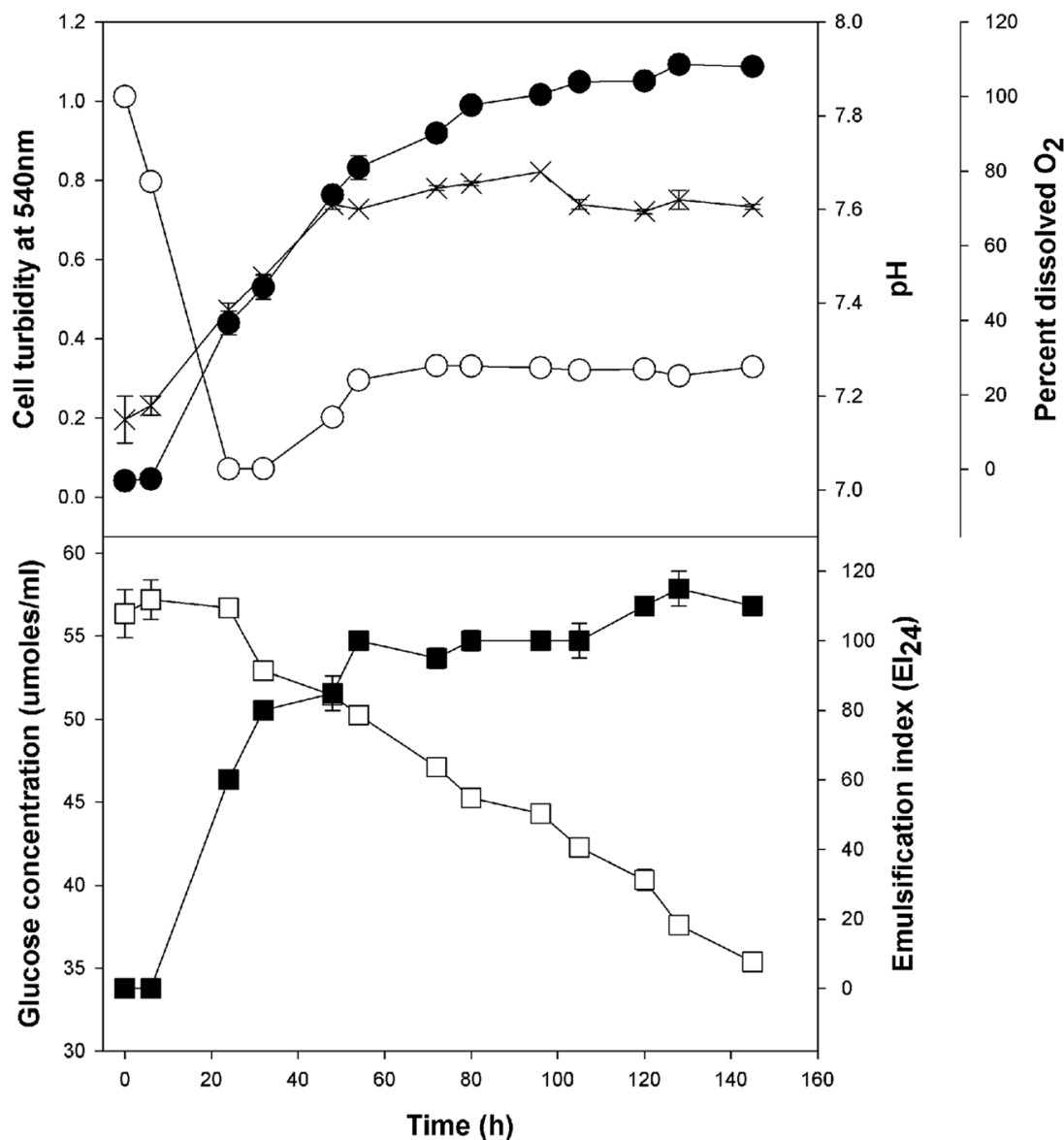

dried polymer (Table 1). The polymer was composed of hexoses (rhamnose, galactose, glucose, mannose), amino sugars

Table 1 Monosaccharide composition of the P39a exopolymer produced by Halomonas sp. strain MCTG39a

\begin{tabular}{|c|c|}
\hline Component & Mean mol\% composition \\
\hline Rhamnose & $35.3 \pm 2.5$ \\
\hline Fucose & Trace \\
\hline Galactose & $19.8 \pm 1.4$ \\
\hline Galactosamine $^{\mathrm{b}}$ & ND \\
\hline Glucose & $16.4 \pm 1.3$ \\
\hline Glucosamine $^{\mathrm{b}}$ & $5.1 \pm 1.2$ \\
\hline Mannose & $6.4 \pm 1.4$ \\
\hline Xylose & $\mathrm{ND}$ \\
\hline Galacturonic acid & $14.3 \pm 1.5$ \\
\hline Glucuronic acid & Trace \\
\hline Total $(\%):^{\mathrm{c}}$ & $17.2 \pm 1.9$ \\
\hline
\end{tabular}

${ }^{\text {a }}$ Values are the mean of triplicate samples \pm standard deviation; ND, not detected

${ }^{\mathrm{b}} \mathrm{N}$-Acetylgalactosamine and $\mathrm{N}$-acetylglucosamine are de-N-acetylated during the acid hydrolysis and are detected as galactosamine and glucosamine

${ }^{\mathrm{c}}$ Total $\%$ values are expressed as the mean percentage of total dry weight of the polymer from triplicate determinations (glucosamine) and the uronic acid galacturonic acid. Rhamnose $(35.3 \% \pm 2.5 \%)$, galactose $(19.8 \% \pm 1.4 \%)$, glucose $(16.4 \% \pm 1.3 \%)$ and galacturonic acid $(14.3 \% \pm 1.5 \%)$ were the most abundant. All other monosaccharides of the P39a exopolymer were each present at less than $10 \%$ and together contributed about $11.5 \% \pm 0.8 \%$ to the total carbohydrate content, with trace quantities of fucose and glucuronic acid detected. The total uronic acid content of the P39a exopolymer was $14.3 \%$, as contributed solely by galacturonic acid.

The total amino acid content of the P39a exopolymer was $36.4 \% \pm 0.4 \%$ (Table 2) of the total weight of dried polymer. Amino acid analysis of hydrolyzed samples identified the presence of four major amino acids - asparagine, glutamine, glycine and alanine - that combined contributed $46.9 \% \pm 0.7 \%$ to the total amino acid content. The percent contribution of hydrophobic nonpolar amino acids to the total amino acid content was $48.0 \%$, whereas that of polar amino acids was $44.3 \%$. Lipid analysis did not reveal any fatty acids.

Analysis of the P39a exopolymer produced by Halomonas sp. strain MCTG39a by SEC-MALLS showed it composed of an average molar mass $\left(M_{w}\right)$ of $261,000 \pm 12,000 \mathrm{~g} / \mathrm{mol}$, with a peak-average molar mass $\left(M_{p}\right)$ of $40,000 \pm 3000 \mathrm{~g} / \mathrm{mol}$. The polydispersity index $\left(M_{w} / M_{n}\right)$ of the polymer was $3.53 \pm 0.13$; 
generally, a polydispersity index of $\geq 1.6$ is indicative of a polydisperse polymer (Harding et al. 1991).

Figure 3a displays the expansion of the $1 \mathrm{D}{ }^{1} \mathrm{H}$ NMR spectrum of the P39a exopolymer reflecting the peptide components of the preparation in addition to a complex carbohydrate spectrum. There is a downfield group of anomeric signals between 4.7 and 5.8 ppm, connected by TOCSY cross-peaks (Fig. 3b; box i) to an envelope of overlapping signals between 3.8 and $4.6 \mathrm{ppm}$, originating from the ring and methylene protons of sugars, in addition to $\alpha$-protons of amino acids. A strong group of signals at about $1.2 \mathrm{ppm}$ may arise from protons at rhamnose $\mathrm{C} 6$, in addition to the alanine methyl group; a peak near 2.4 ppm may include the O-acetyl methyl signal. Other prominent signals in the region between 1.0 and 3.0 ppm, with crosspeaks to the $\alpha$-proton region (Fig. 3b; box ii), reflect the predominance of aliphatic amino acids in the preparation, though the presence of signals between 7.0 and 8.0 ppm indicates a minor proportion of aromatic amino acids.

\section{Emulsification of hydrocarbons and complex oils by the P39a exopolymer}

As shown in Fig. 4, the P39a exopolymer emulsified a range of straight-chain aliphatics, mono- and alkyl-aromatics and cycloparaffins. With a few exceptions, higher emulsification values

Table 2 Amino acid composition of the P39a exopolymer produced by Halomonas sp. strain MCTG39a

\begin{tabular}{ll}
\hline Component & Mean mol\% composition \\
\hline Asparagine & $12.4 \pm 0.1$ \\
Threonine & $6.7 \pm 0.4$ \\
Serine & $5.9 \pm 0.3$ \\
Glutamine & $14.6 \pm 0.2$ \\
Proline & $4.8 \pm 0.5$ \\
Glycine & $10.3 \pm 0.1$ \\
Alanine & $9.6 \pm 0.6$ \\
Cystine & ND \\
Valine & $6.6 \pm 0.2$ \\
Methionine & $2.0 \pm 0.1$ \\
Isoleucine & $4.3 \pm 0.0$ \\
Leucine & $7.1 \pm 0.6$ \\
Tyrosine & $2.3 \pm 0.2$ \\
Phenylalanine & $3.3 \pm 0.1$ \\
Histidine & $2.4 \pm 0.3$ \\
Lysine & $3.3 \pm 0.1$ \\
Arginine & $4.4 \pm 0.2$ \\
Total (\%) & $36.4 \pm 0.4$ \\
\hline
\end{tabular}

${ }^{\text {a }}$ Values are the mean of triplicate samples \pm standard deviation; ND, not detected

${ }^{\mathrm{b}}$ Total $\%$ values are expressed as the mean percentage of total dry weight of the polymer from triplicate determinations were measured in $0.1 \mathrm{M}$ PBS than in FSW, indicating that low ionic strength conditions, and/or possibly a lower $\mathrm{pH}$, are more favourable for emulsification. Conversely, high ionic strength conditions mitigated the polymer's emulsifying capacity. However, we measured higher emulsification values for hexane, hexadecane, 1-phenyldecane and pentadecylbenzene in FSW compared to that in $0.1 \mathrm{M}$ PBS. Emulsions formed with aromatic hydrocarbons (e.g. 2-methylnaphthalene) were quite stable, and emulsification with the refined fossil fuels kerosene, gasoline and diesel also yielded higher emulsifying activities in FSW (Fig. 5). The crude oils Brent and Alwyn, which are respectively heavy and light types of oils, were highly emulsified by the P39a exopolymer, though this was more effective under lower ionic strength conditions.

\section{Effect of the P39a exopolymer on phenanthrene and diesel biodegradation}

Figure 6 shows the polymer's effect on the degradation of phenanthrene by the hydrocarbon-degrader $P$. algicola strain TG408. Degradation followed first-order kinetics in all four treatments with an initial lag of 8, 5, 3 and 0 days in the treatments containing, respectively, $0.0,0.1,0.2$ and $0.4 \mathrm{mg} / \mathrm{ml}$ of the P39a exopolymer. During the time interval between day 5 and 12 , the highest rates of phenanthrene degradation were measured for the treatments with $0.2 \mathrm{mg} / \mathrm{ml}$ and $0.4 \mathrm{mg} / \mathrm{ml}$ of polymer compared to that in treatments with $0.1 \mathrm{mg} / \mathrm{ml}$ or with no added polymer (Table 3 ). Furthermore, the degradation rates for the two treatments with the higher concentrations of the polymer $(0.2$ and $0.4 \mathrm{mg} / \mathrm{ml})$ were statistically similar $(65.7-$ $80.6 \mathrm{mg} / \mathrm{l} /$ day; $P>0.05)$, though significantly higher $(P<0.05)$ compared to that of the $0.1 \mathrm{mg} / \mathrm{ml}$ treatment $(15.2 \mathrm{mg} / \mathrm{l} /$ day $)$ and untreated control (3.6 mg/l/day). More of the phenanthrene was degraded by strain TG408 in incubations with higher concentrations of the P39a polymer, with up to $14.9 \pm 1.5 \%, 11.1 \pm$ $2.0 \%$ and $2.3 \pm 1.5 \%$ degraded in incubations amended with, respectively, $0.4 \mathrm{mg} / \mathrm{ml}, 0.2 \mathrm{mg} / \mathrm{ml}, 0.1 \mathrm{mg} / \mathrm{ml}$ of the polymer compared to only $0.2 \pm 1.4 \%$ degraded in the untreated control. Incubations that were run in parallel showed that strain TG408 did not show measurable growth on the polymer as a carbon source, and no significant transfer of the phenanthrene into the lower aqueous layer was measured in uninoculated incubations containing only the P39a polymer (results not shown).

We also evaluated the effect of the P39a exopolymer on the degradation of diesel by Halomonas sp. strain TGOS-10 that had been isolated from a sea surface oil slick in the Gulf of Mexico during the active phase of the Deepwater Horizon oil spill (Gutierrez et al. 2013b). In the absence of any exogenously added P39a exopolymer, up to $72 \%$ of the diesel was degraded over the 7-day duration of these incubations by the strain TGOS-10 (Fig. 7). The strain exhibited the capacity to degrade the diesel, though we cannot discount that it possibly produced exopolymer during these incubations that may had 
facilitated this. Addition of up to $8 \mathrm{mg} / \mathrm{L}$ of the P39a exopolymer did not significantly improve on the biodegradation of the diesel. However, approximately $10 \%$ more of the diesel was biodegraded by the strain when up to $32 \mathrm{mg} / \mathrm{L}$ of the exopolymer was added.

\section{Discussion}

Over the past two decades has seen increased interest on exopolysaccharides produced by members belonging to the genus Halomonas due to their rheological and/or surface-

a

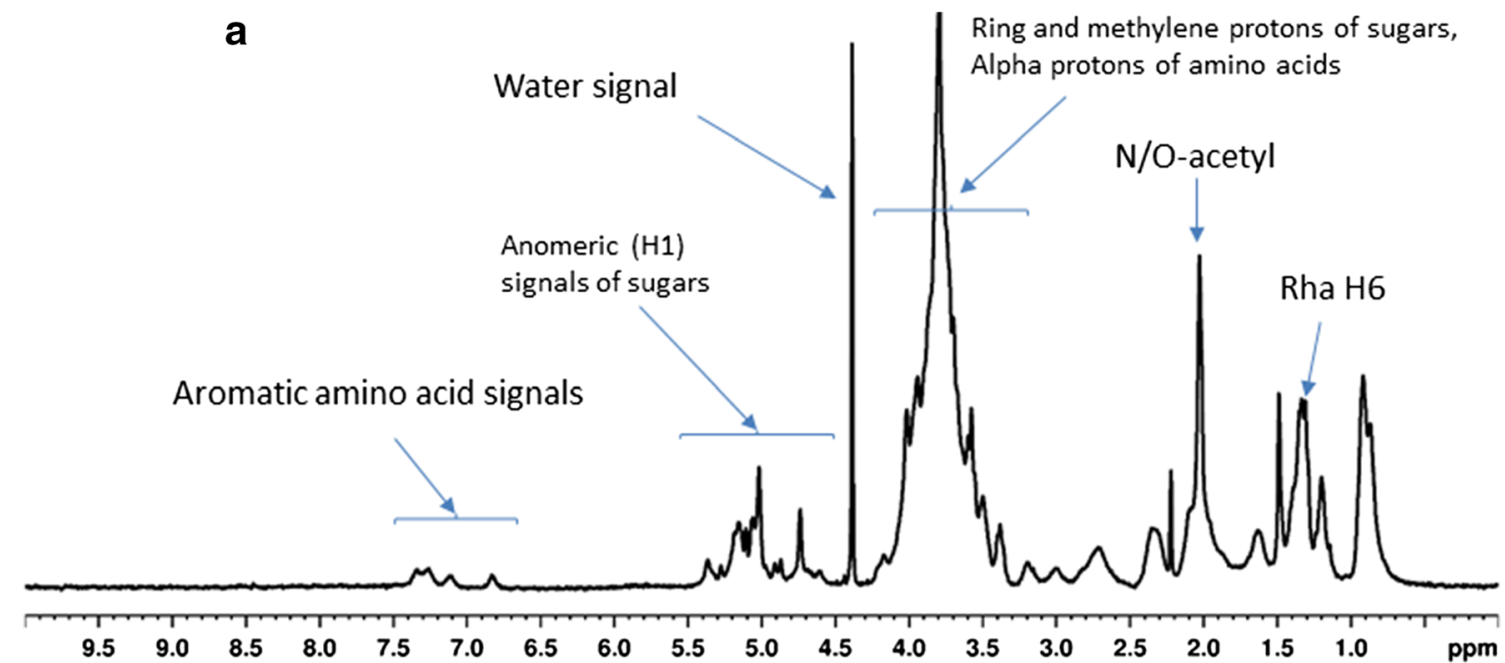

b

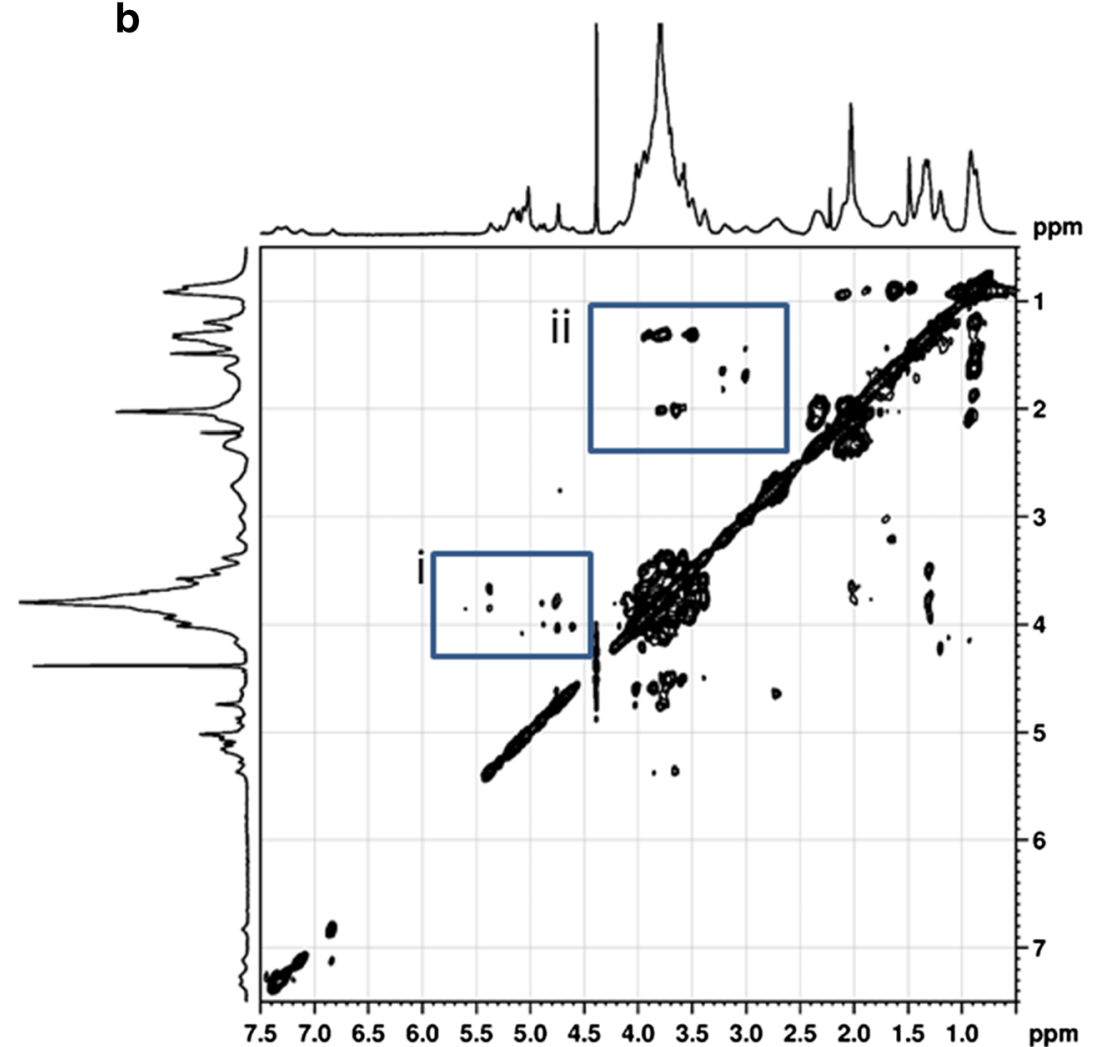

Fig. 3 a Expansion $10.0-0.0$ ppm of the ${ }^{1} \mathrm{H}$ NMR spectrum $(400 \mathrm{MHz}$, $60^{\circ} \mathrm{C}$ in $\mathrm{D}_{2} \mathrm{O}$ ) of the $\mathrm{P} 39$ a exopolymer produced by Halomonas sp. strain MCTG39a. The residual partially deuterated water signal (HOD) is at about 4.8 ppm; b Expansion of the TOCSY spectrum of the same polysaccharide. The blue boxes indicate (i) cross-peaks linking anomeric proton signals between 4.5 and 5.5 ppm to ring and methylene proton signals between 3.5 and $4.3 \mathrm{ppm}$, and (ii) cross-peaks linking signals in the range $1.0-2.2 \mathrm{ppm}$ with signals in the range 2.2 to $4.0 \mathrm{ppm}$, from aliphatic amino acid residues 
Fig. 4 Emulsification of various aliphatic, aromatic and cycloparaffin hydrocarbons by the P39a exopolymer.

Emulsification was performed in 0.1 M phosphate-buffered saline (black bars) or filtered synthetic seawater (grey bars).

Emulsification activity of the lower aqueous phase was measured spectrophotometrically at $540 \mathrm{~nm}$ after allowing the emulsion formed to stand for $10 \mathrm{~min}$, and represents a measure of oilin-water $(\mathrm{O} / \mathrm{W})$ emulsion formation

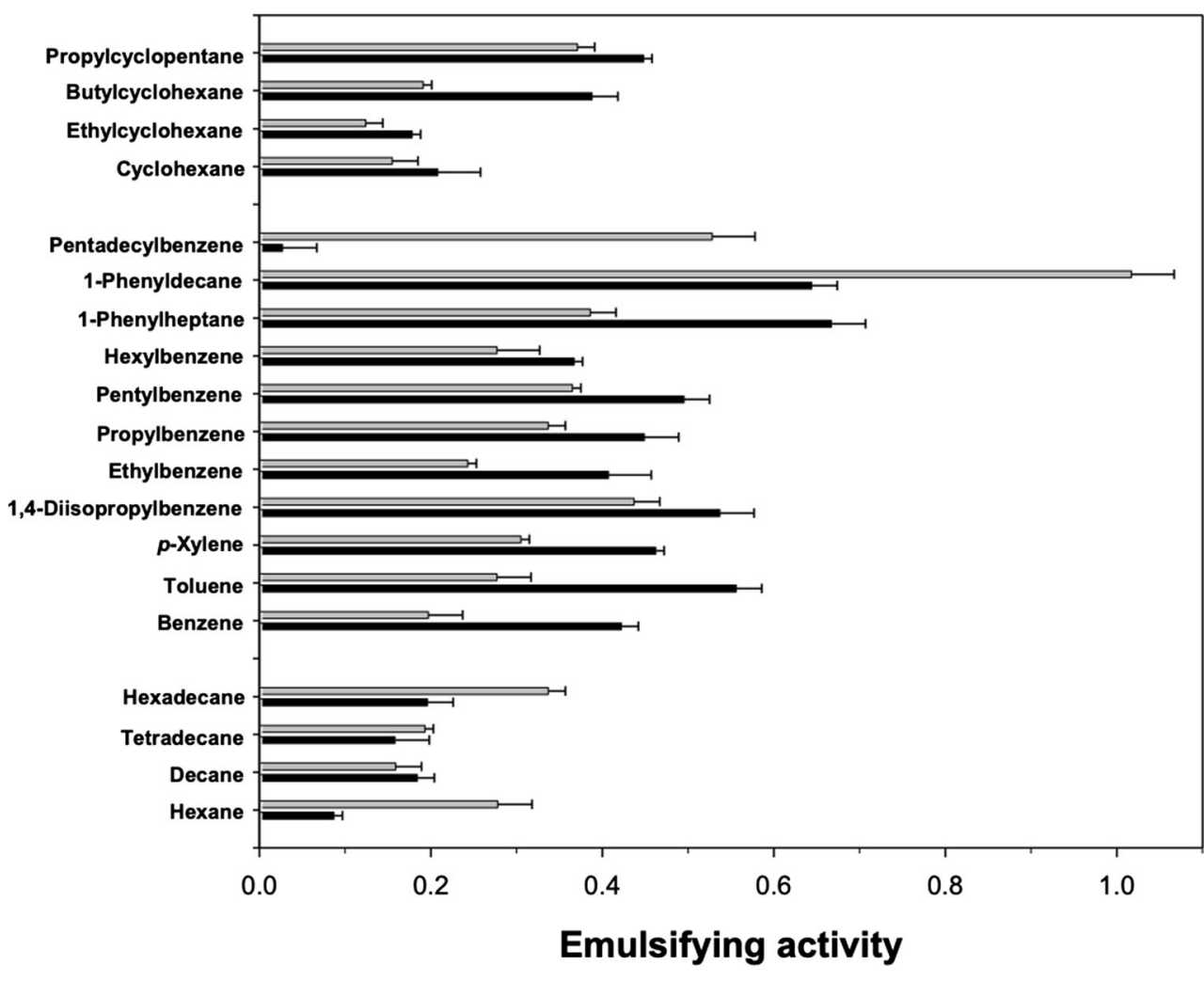

active (i.e. emulsifying or surface tension reducing) properties (Calvo et al. 1998, 2002; Martinez-Checa et al. 2002; Pepi et al. 2005). In this study, we describe the chemical and physical characterization of an extracellular water-soluble emulsifying agent, P39a, produced by a marine Halomonas species, strain MCTG39a.

Screening of a number of isolates for production of surfaceactive agents led to the identification of one isolate, strain MCTG39a, that grew on $n$-hexadecane as the sole carbon and energy source and produced a powerful extracellular emulsifying agent when grown on glucose. Bacteria that produce emulsifiers, like strain MCTG39a, are sometimes categorized based on their production of high-molecular-weight polymers, which primarily act to form stable emulsions (Rosenberg and Ron 1999). During growth in a batch fermenter using ZM/1 medium amended with glucose $(1 \% \mathrm{w} / \mathrm{v})$, emulsifying activity (as a proxy for production of the emulsifying agent) was tightly coupled with growth. As glucose consumption did not cease by $145 \mathrm{~h}$ (the termination of the fermentation), we hypothesized that production of the
Fig. 5 Emulsification of some crude oils and their refined derivatives by the P39a exopolymer. Emulsification was performed in $0.1 \mathrm{M}$ phosphatebuffered saline (black bars) or filtered synthetic seawater (grey bars). Emulsification activity of the lower aqueous phase was measured spectrophotometrically at $540 \mathrm{~nm}$ after allowing the emulsion formed to stand for $10 \mathrm{~min}$, and represents a measure of oil-in-water $(\mathrm{O} / \mathrm{W})$ emulsion formation

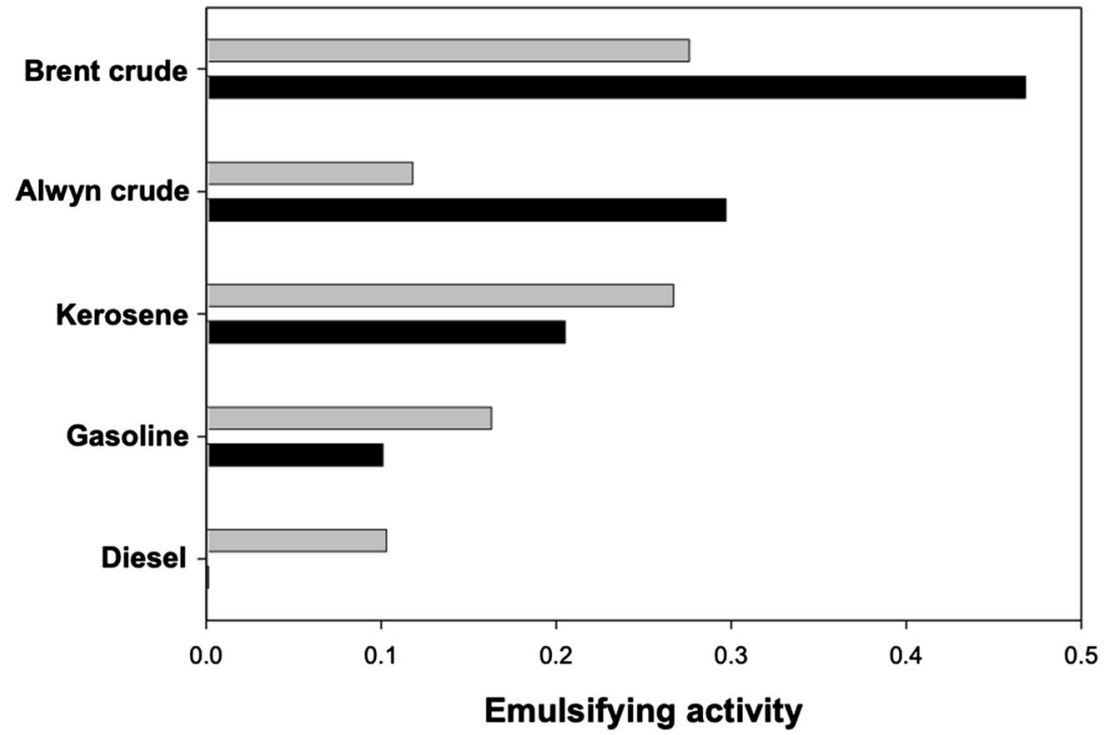


emulsifier could have continued should the culture have been left to proceed for longer. However, by this phase in the fermentation, we did not measure higher $\mathrm{EI}_{24}$ values for dilutions of the cell-free spent medium, suggesting that production of the emulsifying P39a exopolymer reached maximal yields by this point.

With the exception of rhamnose, the monosaccharide composition of the P39a exopolymer is concomitant with that of other bacterial exopolymers, which are generally rich in hexoses, like glucose and galactose (Manusco Nichols et al. 2005; Sutherland 1999). Variations in monomer composition of exopolymers can alter their properties. For example, arabinose in bacterial exopolymers aid in cell aggregation (Bahat-Samet et al. 2004), whereas deoxy sugars, like fucose and rhamnose that are found in diatom exopolymers, can mediate foaming and flocculation (Zhou et al. 1998). We note, however, that arabinose and xylose are not commonly found in bacterial exopolymers (Kenne and Lindberg 1983), and not unexpectedly they were not detected in the P39a exopolymer. Conversely, xylose was detected in an exopolymer produced by the closely related strain Halomonas sp. TG39, albeit in minor quantities $(0.8 \%$ of total weight of dried polymer) (Gutierrez et al. 2007). The uronic acids content of the P39a exopolymer is a little below, but comparable to, the uronic acids composition (typically $20-50 \%$ of total carbohydrate content) that are generally found in exopolymers produced by marine bacteria (Kennedy and Sutherland 1987; Manusco Nichols et al. 2005). Unlike the exopolymer produced by Halomonas sp. TG39 which contains glucuronic acid (27.9\%) as the major uronic acid (Gutierrez et al. 2007), this acid in the P39a exopolymer is present in trace quantities. Uronic acids contain an acidic carboxyl group that is ionisable at seawater $\mathrm{pH}$, and which contributes a negative charge to the

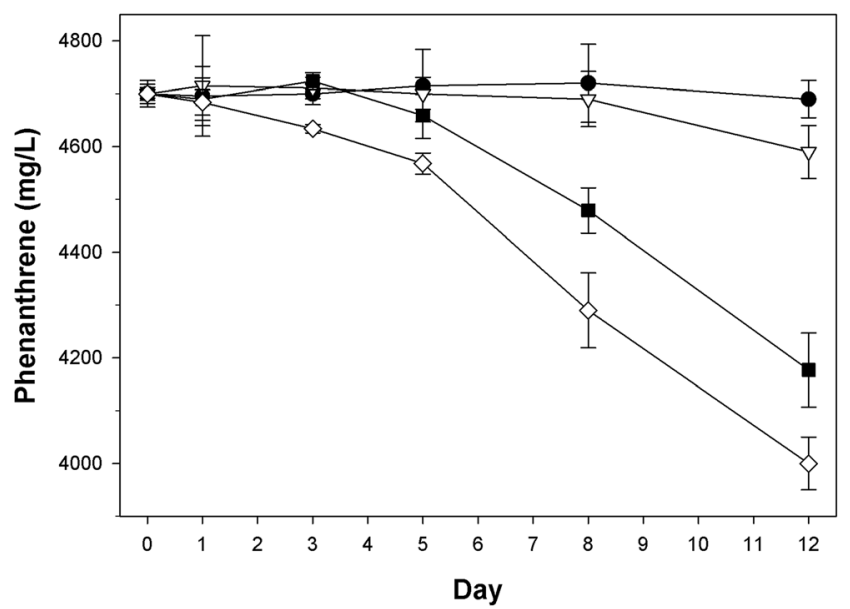

Fig. 6 Effect of the P39a exopolymer on the degradation of phenanthrene by Polycyclovorans algicola strain TG408. Each data point is the mean of results from triplicate samples and represents the residual concentration of phenanthrene. Concentrations of the exopolymer tested were $0 \mathrm{mg} / \mathrm{ml}$ (solid circles), $0.1 \mathrm{mg} / \mathrm{ml}$ (inverted triangles), $0.2 \mathrm{mg} / \mathrm{ml}$ (solid squares) and $0.4 \mathrm{mg} / \mathrm{ml}$ (diamonds). Some error bars are smaller than the symbols
Table 3 Rates and extent to which phenanthrene was degraded during incubation of $P$. algicola strain $\mathrm{TG} 408^{\mathrm{T}}$ on increasing concentrations of the P39a exopolymer

Incubations using $P$. algicola TG408

\begin{tabular}{llll}
\hline $\begin{array}{l}\text { EPS } \\
(\mathrm{mg} / \mathrm{ml})\end{array}$ & $\begin{array}{l}\text { Lag } \\
(\text { days })\end{array}$ & $\begin{array}{l}\text { Rate at 5-12 days } \\
(\mathrm{mg} / \mathrm{l} / \text { day })\end{array}$ & $\begin{array}{l}\text { Extent degraded after 12 days } \\
(\%)^{\mathrm{a}}\end{array}$ \\
\hline 0.0 & 8 & $3.6 \pm 11.2$ & $0.2 \pm 1.4$ \\
0.1 & 5 & $15.2 \pm 13.2$ & $2.3 \pm 1.5$ \\
0.2 & 3 & $65.7 \pm 17.7$ & $11.1 \pm 2.0$ \\
0.4 & 0 & $80.6 \pm 24.3$ & $14.9 \pm 1.5$ \\
\hline
\end{tabular}

${ }^{\text {a }}$ Percentage degraded of total initial phenanthrene

overall polymer (Decho and Gutierrez 2017). The carboxylate and methoxycarbonyl groups of these types of acidic sugars can mediate the adsorption of biopolymers to hydrophobic surfaces, such as oil droplets, and in turn stabilize the droplets into emulsions in aqueous media (Dea and Madden 1986; Kaplan et al. 1987; Tolstogusov 1991, 1994). The presence also of 6-deoxyhexoses (e.g. rhamnose) and increased substitution by acetyl moieties (NMR peak near $2.4 \mathrm{ppm}$ ) on the P39a exopolymer (see below) can also render these types of macromolecules with surface-active qualities (Dea and Madden 1986; Graber et al. 1988).

The relatively high protein content $(36.4 \%$ of total polymer; Table 2) of the P39a exopolymer produced by this strain is consistent with that of other marine Halomonas species (Gutierrez et al. 2007, 2013b; Bèjar et al. 1998). For example, the protein content of the exopolymer produced by Halomonas sp. TG39 was 26.6\% (Gutierrez et al. 2007), though $10 \%$ lower compared to that of the P39a exopolymer. Exopolymers produced by other halomonads have also been

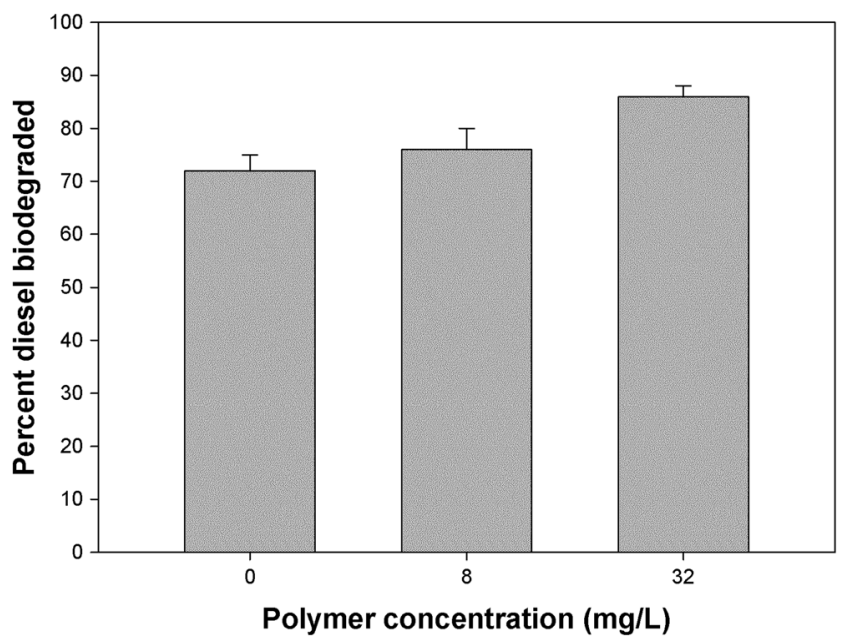

Fig. 7 Effect of the P39a exopolymer on the degradation of diesel by Halomonas sp. strain TGOS-10. Concentrations of the exopolymer tested were 0,8 and $32 \mathrm{mg} / \mathrm{L}$. Bars represent the percentage of diesel degraded by strain TGOS-10 after a 7-day incubation 
found to contain a protein component, and although at lower concentrations ( $<10 \%$ of total polymer), it has been inferred to contribute to the emulsifying qualities of the polymers (Arias et al. 2003; Llamas et al. 2012; Quesada et al. 1993; Mata et al. 2006). Indeed, proteins can play an essential role in the emulsifying ability of some bacterial exopolysaccharides (Rosenberg et al. 1979a; Navon-Venezia et al. 1998), including for exopolymers produced by different Halomonas species (Mata et al. 2008; Llamas et al. 2012); we suspect the protein component of the P39a exopolymer confers a similar function, as may be effected by the ratio of total hydrophobic nonpolar to polar amino acids. This ratio was 1.1:1.0 for the P39a exopolymer, whereas it was found to be 0.6:1.0 for the exopolymer produced by the closely related strain Halomonas sp. TG39 (Gutierrez et al. 2007). The NMR results are consistent with a complex glycoprotein structure for the P39a exopolymer, consisting of both carbohydrate and peptide components. Interestingly, this contrasts with reports of EPS structures from other halomonads: the carbohydrate part of the sample is not a simple homopolymer such as that described for the exopolysaccharide of Halomonas sp. AAD6 (JCM 15723) strain (Poli et al. 2009), but a more complex compound. In addition, the monosaccharide composition of the carbohydrate is not the same as for the exopolysaccharide of Halomonas strain CRSS (Poli et al. 2004).

As polydispersity provides an indication of the molecular size distribution of a polymer in solution, a higher than 1.6 polydispersity index value for the P39a exopolymer denotes that it is heterogenous compared to, for example, commercially available pullulan $\left(I_{p} \leq 1.1\right)$. As the polymer is highly polydisperse, it is worthy to note that the weight-average is highly influenced by a small amount of very high-molecular-weight species of the exopolymer. It should be noted that the weightaverage molecular weight of a mixture of components will be biased toward higher molecular weights due to the way weightaverage molecular weights are calculated. This behaviour can result from the high content of anionic moieties, such as those found present on uronic acids, which are typically enriched in marine bacterial exopolymers (Decho and Gutierrez 2017).

Exopolymers from various species of Halomonas have been shown to emulsify hydrocarbons, crude oils and refined petroleum products (Bouchotroch et al. 2000; Calvo et al. 1998, 2002; Gutierrez et al. 2007, 2009; Martinez-Checa et al. 2002; Mata et al. 2006; Pepi et al. 2005). However, for the marine environment, there remains a paucity of knowledge pertaining to the importance of EPS produced by members of this genus and other EPS-producing bacteria to influencing the degradation of hydrocarbons. Here, we evaluated various hydrocarbons and complex oils as substrates for emulsification by the P39a exopolymer under low (0.1 M PBS) and high (FSW) ionic strength conditions, and show that high ionic strength conditions mitigated the polymer's emulsifying capacity. We posit that this could be attributed to the presence of higher concentration of cations in reducing the polymer's anionic charge. Our previous work with another Halomonas polymer showed how high ionic strength conditions can effectively reduce its cation-binding potential (Gutierrez et al. 2009). We posit that cationic species in FSW (e.g. $\mathrm{Na}^{+}$) would be able to neutralize anionic groups, such as sulphate and carboxyl residues, of the polymer and render it less capable of emulsifying hydrocarbon substrates (Gutierrez et al. 2009).

However, we measured higher emulsification values for hexane, hexadecane, 1-phenyldecane and pentadecylbenzene in FSW compared to that in $0.1 \mathrm{M}$ PBS, suggesting that, at least for some hydrocarbon species such as these, the protein fraction of the polymer is likely to have contributed to their emulsification. This concurs with our earlier assumption that the protein component of the polymer plays an important role in emulsification. Furthermore, we also observed that the emulsions formed with aromatic hydrocarbons (e.g. 2-methylnaphthalene) were quite stable, suggesting that the P39a exopolymer likely interacts directly with the aromatic hydrocarbons by possibly steric adsorption at the oil droplet interface. The observed high emulsifying activities in FSW with the refined fossil fuels kerosene, gasoline and diesel could possibly be explained by the inherent properties of these oils, which contain higher levels of hydrocarbon species that are more effectively emulsified by the protein fraction of the polymer. Conversely, the crude oils Brent and Alwyn, which are respectively heavy and light types of oils, were more highly emulsified by the P39a exopolymer in lower ionic strength conditions, and this differential emulsifying selectivity for hydrocarbons has been reported elsewhere for other amphiphilic bacterial polymers, such as emulsan (Rosenberg et al. 1979b). A mechanism to explain this for the P39a exopolymer, however, remains unclear to us at present. Overall, the polymer displayed higher emulsifying activities for mono- and alkylaromatic hydrocarbons than for straight-chain aliphatics or cycloparaffins. From an ecological standpoint, this higher apparent hydrocarbon specificity for aromatics suggests that the P39a exopolymer may interact with aromatic species, such as humic substances, in the marine environment. We suspect that this interaction could potentially increase the bioavailability of these terrestrial-derived, complex aromatic substances in the water column for microbial biodegradation.

The ability of the P39a exopolymer to enhance the biodegradation of phenanthrene by other bacteria, such as the hydrocarbonoclastic marine strain $P$. algicola TG408, demonstrates the versatility of this exopolymer to enhance the bioavailability of hydrocarbon substrates to bacteria other than the producing strain, Halomonas sp. MCTG39a. During these experiments, the inability of $P$. algicola TG408 to utilise the exopolymer as a carbon and energy source could be explained, at least in part, by the polymer's uronic acids content (Anton et al. 1988; Bèjar et al. 1996), or glycosidic linkages of hexosamines (Biermann 1988), which can increase the 
refractory nature of marine exopolymers to biodegradation (Ogawa et al. 2001).

Many species of Halomonas have been shown to degrade mono-aromatic (Abdelkafi et al. 2006; Garcia et al. 2004, 2005; Hinteregger and Streichsbier 1997; Munoz et al. 2001), polycyclic aromatic (Melcher et al. 2002; Calvo et al. 2002; Martinez-Checa et al. 2002; Yang et al. 2010) and aliphatic (Mnif et al. 2009; Pepi et al. 2005; Bouchotroch et al. 2000) hydrocarbons. Here, we evaluated the effect of the P39a exopolymer on the degradation of diesel by Halomonas sp. strain TGOS-10 that was isolated from a sea surface oil-slick sample in the Gulf of Mexico during the Deepwater Horizon oil spill (Gutierrez et al. 2013b). Interestingly, only the higher concentrations used of exogenously added P39a exopolymer effected an enhanced degradation of diesel by the strain. Petroleum diesel oil is a complex mixture of hydrocarbons that typically contain between 8 and 21 carbon atoms per molecule. The organic composition of diesel includes $n$-alkanes, branched alkanes, saturated cycloalkanes, PAHs, alkylated PAHs and alkylbenzenes which account for $27.90 \%, 53.87 \%, 7.72 \%, 0.26 \%, 3.70 \%$ and $6.55 \%$, respectively, to its composition (Pál et al. 1998). Based on the ability of the P39a exopolymer to effectively emulsify a range of individual hydrocarbon species (Fig. 4), the combination of de novo synthesised exopolymer by strain TGOS-10 and its exogenous supplementation when added to $32 \mathrm{mg} / \mathrm{L}$ final concentration would have likely served to bolster the strain's biodegradation of the diesel oil.

Acknowledgements We thank David Caron of the University of Southern California for providing the seawater sample from Long Beach, California. We also thank the two anonymous reviewers for their valuable comments during the preparation of the manuscript.

Funding information This study was funded by a Marie Curie International Outgoing Fellowship (PIOF-GA-2008-220129) within the 7th European Community Framework Programme awarded to TG. Partial support was provided from the European Union Framework Programme for Research and Innovation, Horizon 2020 under Grant agreement No. 635340 MARISURF.

\section{Compliance with ethical standards}

Conflict of interest The authors declare that they have no conflict of interest.

Ethical approval The article does not contain any studies with human participants or animals performed by any of the authors.

Open Access This article is licensed under a Creative Commons Attribution 4.0 International License, which permits use, sharing, adaptation, distribution and reproduction in any medium or format, as long as you give appropriate credit to the original author(s) and the source, provide a link to the Creative Commons licence, and indicate if changes were made. The images or other third party material in this article are included in the article's Creative Commons licence, unless indicated otherwise in a credit line to the material. If material is not included in the article's
Creative Commons licence and your intended use is not permitted by statutory regulation or exceeds the permitted use, you will need to obtain permission directly from the copyright holder. To view a copy of this licence, visit http://creativecommons.org/licenses/by/4.0/.

\section{References}

Abdelkafi S, Labat M, Casalot L, Chamkha M, Sayadi S (2006) Isolation and characterization of Halomonas sp. IMPC, a $p$-coumaric acidmetabolizing bacterium that decarboxylates other cinnamic acids under hypersaline conditions. FEMS Microbiol Lett 255:108-114

Alva VA, Peyton BM (2003) Phenol and catechol biodegradation by the haloalkaliphile Halomonas campisalis: influence of $\mathrm{pH}$ and salinity. Environ Sci Technol 37:4397-4402

Anton J, Meseguer I, Rodriguezvalera F (1988) Production of an extracellular polysaccharide by Haloferax-mediterranei. Appl Environ Microbiol 54:2381-2386

Arahal DR, Ventosa A (2006) The family Halomonadaceae. In: Dworkin M, Falkow S, Eosenberg E, Schleifer K-H, Stackebrandt E (eds) The prokaryotes: a handbook on the biology of bacteria, vol 6, 3rd edn. Springer Science, Singapore, pp 811-835

Arias S, del Moral A, Ferrer MR, Tallon R, Quesada E, Bejar V (2003) Mauran, an exopolysaccharide produced by the halophilic bacterium Halomonas maura, with a novel composition and interesting properties for biotechnology. Extremophiles 7:319-326

Bahat-Samet E, Castro-Sowinski S, Okon Y (2004) Arabinose content of extracellular polysaccharide plays a role in cell aggregation of Azospirillum brasilense. FEMS Microbiol Lett 237:195-203

Bèjar V, Calvo C, Moliz J, Diaz-Martinez F, Quesada E (1996) Effect of growth conditions on the rheological properties and chemical composition of Volcaniella eurihalina exopolysaccharide. Appl Biochem Biotechnol 59:77-86

Bèjar V, Llamas I, Calvo C, Quesada E (1998) Characterization of exopolysaccharides produced by 19 halophilic strains of the species Halomonas eurihalina. J Biotechnol 61:135-141

Biermann CJ (1988) Hydrolysis and other cleavages of glycosidic linkages in polysaccharides. Adv Carbohydr Chem Biochem 46:251271

Blackburn SI, Hallegraeff GM, Bolch CJ (1989) Vegetative reproduction and sexual life cycle of the toxic dinoflagellate Gymnodinium catenatum from Tasmania, Australia. J Phycol 25:577-590

Bouchotroch S, Quesada E, Izquierdo I, Rodriguez M, Bejar V (2000) Bacterial exopolysaccharides produced by newly discovered bacteria belonging to the genus Halomonas, isolated from hypersaline habitats in Morocco. J Ind Microbiol Biotechnol 24:374-378

Calvo C, Martinez-Checa F, Mota A, Quesada E (1998) Effect of cations, $\mathrm{pH}$ and sulfate content on the viscosity and emulsifying activity of the Halomonas eurihalina exopolysaccharide. J Ind Microbiol Biotechnol 20:205-209

Calvo C, Martinez-Checa F, Toledo FL, Porcel J, Quesada E (2002) Characteristics of bioemulsifiers synthesized in crude oil media by Halomonas eurihalina and their effectiveness in the isolation of bacteria able to grow in the presence of hydrocarbons. Appl Microbiol Biotechnol 60:347-351

Cirigliano MC, Carman GM (1984) Isolation of a bio-emulsifier from Candida lipolytica. Appl Environ Microbiol 48:747-750

Cooper DG, Goldenberg BG (1987) Surface-active agents from two Bacillus species. Appl Environ Microbiol 53:224-229

Dea ICM, Madden JK (1986) Acetylated pectic polysaccharides of sugar beet. Food Hydrocoll 1:71-88 
Decho AW (2000a) Exopolymer microdomains as a structuring agent for heterogeneity with microbial biofilms. In: Riding RE, Awramik SM (eds) Microbial Sediments. Springer-Verlag Press, Berlin, pp 9-15

Decho AW (2000b) Microbial biofilms in intertidal systems: an overview. Cont Shelf Res 20:1257-1273

Decho AW, Gutierrez T (2017) Microbial extracellular polymeric substances (EPSs) in ocean systems. Front Microbiol 8:922

Dyksterhouse SE, Gray JP, Herwig RP, Cano Lara J, Staley JT (1995) Cycloclasticus pugetii gen. nov., sp.nov., an aromatic hydrocarbondegrading bacterium from marine sediments. Int J Syst Bacteriol 45: $116-123$

Garcia MT, Mellado E, Ostos JC, Ventosa A (2004) Halomonas organivorans sp. nov., a moderate halophile able to degrade aromatic compounds. Int J Syst Evol Microbiol 54:1723-1728

Garcia MT, Ventosa A, Mellado E (2005) Catabolic versatility of aromatic compound-degrading halophilic bacteria. FEMS Microbiol Ecol 54:97-109

Graber M, Morin A, Duchiron F, Monsan PF (1988) Microbial polysaccharides containing 6-deoxysugars. Enzym Microb Technol 10: 198-206

Gutierrez T, Mulloy B, Black K, Green DH (2007) Glycoprotein emulsifiers from two marine Halomonas species: chemical and physical characterization. J Appl Microbiol 103:1716-1727

Gutierrez T, Shimmield T, Haidon C, Black K, Green DH (2008) Emulsifying and metal ion binding activity of a glycoprotein exopolymer produced by Pseudoalteromonas species TG12. Appl Environ Microbiol 74:4867-4876

Gutierrez T, Morris G, Green DH (2009) Yield and physicochemical properties of EPS from Halomonas sp. strain TG39 identifies a role for protein and anionic residues (sulfate and phosphate) in emulsification of $n$-hexadecane. Biotechnol Bioeng 103:207-216

Gutierrez T, Green DH, Whitman WB, Nichols PD, Semple KT, Aitken MD (2013a) Polycyclovorans algicola gen. nov., sp. nov., an aromatic hydrocarbon-degrading marine bacterium found associated with laboratory cultures of marine phytoplankton. Appl Environ Microbiol 79:205-214

Gutierrez T, Berry D, Yang T, Mishamandani S, McKay L, Teske A, Aitken M (2013b) Role of bacterial exopolysaccharides (EPS) in the fate of the oil released during the Deepwater Horizon oil spill. PLoS One 8(6):e67717

Harding SE, Vårum KM, Stokke BT, Smidsrød O (1991) Molecular weight determination of polysaccharides. In: White CA (ed) Advances in carbohydrate analysis, vol 1. JAI Press Ltd, Greenwich, pp 63-144

Hinteregger C, Streichsbier F (1997) Halomonas sp., a moderately halophilic strain, for biotreatment of saline phenolic waste-water. Biotechnol Lett 19:1099-1102

Kalogerakis N, Arff J, Banat IM, Broch CJ, Daffonchio D, Edvardsen T, Eguiraun H, Giuliano L, Handå A, López-de-Ipiña K, Marigomez I, Martinez I, Øle G, Rojo F, Skjermo J, Zanaroli G, Fava F (2015) The role of environmental biotechnology in exploring, exploiting, monitoring, preserving, protecting and decontaminating the marine environment. New Biotechnol 32:157-167

Kaplan N, Zosim Z, Rosenberg E (1987) Reconstitution of emulsifying activity of Acinetobacter calcoaceticus BD4 emulsan by using pure polysaccharide and protein. Appl Environ Microbiol 53:440-446

Katsivela E, Moore ERB, Kalogerakis N (2003) Biodegradation of aliphatic and aromatic hydrocarbons: specificity among bacteria isolated from refinery waste sludge. Water Air Soil Pollut 3:103-115

Kenne L, Lindberg B (1983) Bacterial polysaccharides. In: Aspinall GO (ed) The polysaccharides. Academic Press, New York, pp 287-363

Kennedy AFD, Sutherland IW (1987) Analysis of bacterial exopolysaccharides. Biotechnol Appl Biochem 9:12-19

Lane DJ (1991) 16S/23S rRNA sequencing. In: Stackebrandt E, Goodfellow M (eds) Nucleic acid sequencing techniques in bacterial systematics. Wiley, New York, pp 115-175
Llamas I, Amjres H, Mata JA, Quesada E, Bèjar V (2012) The potential biotechnological applications of the exopolysaccharide produced by the halophilic bacterium Halomonas almeriensis. Molecules 17: 7103-7120

Loaec M, Olier R, Guezennec J (1997) Uptake of lead, cadmium and zinc by a novel bacterial exopolysaccharide. Water Res 31:1171-1179

Loaec M, Olier R, Guezennec J (1998) Chelating properties of bacterial exopolysaccharides from deep-sea hydrothermal vents. Carbohydr Polym 35:65-70

Maidak BL, Cole JR, Parker CT Jr, Garrity GM, Larsen N, Li B, Liburn TG, McCaughey MJ, Olsen GJ, Overbeek R, Pramanik S, Schmidt TM, Tiedje JM, Woese CR (1999) A new version of the RDP (Ribosomal Database Project). Nucleic Acids Res 27:171-173

Manusco Nichols CA, Garon Lardiere S, Bowman JP, Nichols PD, Gibson JAE, Guezennec J (2005) Chemical characterization of exopolysaccharides from Antarctic marine bacteria. Microb Ecol 49:578-589

Martinez-Checa F, Toledo FL, Vilchez R, Quesada E, Calvo C (2002) Yield production, chemical composition, and functional properties of emulsifier $\mathrm{H} 28$ synthesized by Halomonas eurihalina strain $\mathrm{H}-28$ in media containing various hydrocarbons. Appl Microbiol Biotechnol 58:358-363

Mata JA, Bejar V, Llamas I, Arias S, Bressollier P, Tallon R, Urdaci MC, Quesada E (2006) Exopolysaccharide produced by the recently described halophilic bacteria Halomonas ventosae and Halomonas anticariensis. Res Microbiol 157:827-835

Mata JA, Béjar V, Bressollier P, Tallon R, Urdaci MC, Quesada E, Llamas I (2008) Characterization of exopolysaccharides produced by three moderately halophilic bacteria belonging to the family Alteromonadaceae. J Appl Microbiol 105:521-528

Melcher RJ, Apitz SE, Hemmingsen BB (2002) Impact of irradiation and polycyclic aromatic hydrocarbon spiking on microbial populations in marine sediment for future aging and biodegradability studies. Appl Environ Microbiol 68:2858-2868

Mnif S, Chamkha M, Sayadi S (2009) Isolation and characterization of Halomonas sp. strain C2SS100, a hydrocarbon-degrading bacterium under hypersaline conditions. J Appl Microbiol 107:785-794

Munoz JA, Perez-Esteban B, Esteban M, De La Escalera S, Gomez MA, Martinez-Toledo MV, Gonzalez-Lopez J (2001) Growth of moderately halophilic bacteria isolated from sea water using phenol as the sole carbon source. Folia Microbiol 46:297-302

Navon-Venezia S, Banin E, Ron EZ, Rosenberg E (1998) The bioemulsifier alasan: role of protein in maintaining structure and activity. Appl Microbiol Biotechnol 49:382-384

Ogawa H, Amagai Y, Koike I, Kaiser K, Benner R (2001) Production of refractory dissolved organic matter by bacteria. Science 292:917920

Page RDM (1996) TREEVIEW: an application to display phylogenetic trees on personal computers. Comput Appl Biosci 12:357-358

Pál R, Juhász M, Stumpf Á (1998) Detailed analysis of hydrocarbon groups in diesel range petroleum fractions with on-line coupled supercritical fluid chromatography-gas chromatography-mass spectrometry. J Chromatogr 819:249-257

Panilaitis B, Castro GR, Solaiman D, Kaplan DL (2006) Biosynthesis of emulsan biopolymers from agro-based feedstocks. J Appl Microbiol 102:531-537

Pepi M, Cesaro A, Liut G, Baldi F (2005) An antarctic psychrotrophic bacterium Halomonas sp. ANT-3b, growing on $n$-hexadecane, produces a new emulsifying glycolipid. FEMS Microbiol Ecol 53:157166

Poli A, Moriello VS, Esposito E, Lama L, Gambacorta A, Nicolaus B (2004) Exopolysaccharide production by a new Halomonas strain CRSS isolated from saline lake Cape Russell in Antarctica growing on complex and defined media. Biotechnol Lett 26:1635-1638

Poli A, Kazak H, Gürleyendağ B, Tommonaro G, Pieretti G, Toksoy Öner E, Nicolaus B (2009) High level synthesis of levan by a novel 
Halomonas species growing on defined media. Carbohydr Polym 78:651-657

Quesada E, Béjar V, Calvo C (1993) Exopolysaccharide production by Volcaniella eurihalina. Experientia 49:1037-1041

Rontani JF, Giusti G (1986) Study of the biodegradation of poly-branched alkanes by a marine bacterial community. Mar Chem 20:197-205

Rosenberg E, Ron EZ (1999) High- and low-molecular-mass microbial surfactants. Appl Microbiol Biotechnol 52:154-162

Rosenberg E, Zuckerberg A, Rubinovitz C, Gutnick DL (1979a) Emulsifier of Arthrobacter RAG-1: isolation and emulsifying properties. Appl Environ Microbiol 37:402-408

Rosenberg E, Perry A, Gibson DT, Gutnick DL (1979b) Emulsifier of Arthrobacter RAG-1: specificity of hydrocarbon substrate. Appl Environ Microbiol 37:409-413

Sanchez-Porro C, Kaur B, Mann H, Ventosa A (2010) Halomonas titanicae sp. nov., a halophilic bacterium isolated from the RMS titanic. Int J Syst Evol Microbiol 60:2768-2774

Steiner AE, McLaren DA, Forster CF (1976) The nature of activated sludge flocs. Water Res 10:25-30

Summers S, Henry T, Gutierrez T (2018) Agglomeration of nano- and microplastic particles in seawater by autochthonous and de novoproduced sources of exopolymeric substances. Mar Pollut Bull 130: $258-267$

Sutherland IW (1999) In: Wingender J, Neu TR, Flemming HC (eds) Microbial extracellular polymeric substances. Springer Publications, Berlin

Thavasi R, Banat IM (2014) Biosurfactant and bioemulsifiers from marine sources. In: Mulligan CN, Sharma SK, Hardback MA (eds) Biosurfactants: Research Trends and Applications, Chap. 5. CRC Press, Boca Raton, pp 125-146

Theisen A, Johann C, Deacon MP, Harding SE (2000) Refractive increment data-book for polymer and biomolecular scientists. Nottingham University Press, Nottingham
Thomas O, Burgess C (2007) UV-visible spectrophotometry of water and wastewater: techniques and instrumentation in analytical chemistry. Elsevier, Amsterdam

Thompson JD, Higgins DG, Gibson TJ (1994) CLUSTAL_X: improving the sensitivity of progressive multiple sequence alignment through sequence weighting, position-specific gap penalties and weight matrix choice. Nucleic Acids Res 22:4673-4680

Tolstogusov VB (1991) Functional properties of food proteins and the role of protein-polysaccharide interaction. Food Hydrocoll 4:429 468

Tolstogusov VB (1994) Some physico-chemical aspects of protein processing in foods. In: Phillips GO, Williams PA, Wed-lock DJ (eds) Gums and Stabilizers for the Food Industry. IRL Press, Oxford, pp 115-124

Wilmotte A, Van der Auwera G, De Wachter R (1993) Structure of the $16 \mathrm{~S}$ ribosomal RNA of the thermophilic cyanobacterium Chlorogloeopsis HTF ('Mastigocladus laminosus HTF') strain PCC7518, and phylogenetic analysis. FEMS Microbiol Lett 317: 96-100

Wodzinski RS, Larocca D (1977) Bacterial growth kinetics on diphenylmethane and naphthalene-heptamethylnonane mixtures. Appl Environ Microbiol 33:660-665

Yang C, Wang Z, Li Y, Niu Y, Du M, He X, Ma C, Tang H, Xu P (2010) Metabolic versatility of halotolerant and alkaliphilic strains of Halomonas isolated from alkaline black liquor. Bioresour Technol 101:6778-6784

Zhou J, Mopper K, Passow U (1998) The role of surface-active carbohydrates in the formation of transparent exopolymer particles by bubble adsorption of seawater. Limnol Oceanogr 43:1860-1871

Publisher's note Springer Nature remains neutral with regard to jurisdictional claims in published maps and institutional affiliations. 